\title{
LEVEL KNOWLEDGE OF CATARACT, EDUCATION, AND SOSIOECONOMIC STATUS WITH PREOPERATIVE VISUAL ACUITY IN PATIENTS WITH SENILE CATARACT IN PHC HOSPITAL OF SURABAYA
}

\author{
Yordani Sumomba $^{1)}$, Titiek Ernawati ${ }^{2)}$, Florentina Sustini ${ }^{3)}$
}

\begin{abstract}
Introduction : Cataract is a cloudiness in the fibers or lens material inside the lens capsule. If the cataract was not treated immediately, the patient might experience blindness.

Aim: This study aimed to analyze the correlation between the level of knowledge about cataract, education, and socioeconomic status with preoperative visual acuity in patients with senile cataract in hospital PHC Surabaya.

Methods : This study was observational analytic with sampling through accidental sampling. The sample of the study was senile cataract patients preoperatively on August $24^{\text {th }}$ to $27^{\text {th }}$ September 2016. The variables of the study was the level of knowledge about cataract, education level, socioeconomic status, and preoperative visual acuity. Data analysis used Spearman correlation test.

Results : Results obtained preoperatively senile cataract patients was highest in the age group 60-64 years (28\%) and the lowest in the age group 75-79 years $(6 \%)$. By gender, patients of senile cataract was highest in the group of male $(52 \%)$ than female $(48 \%)$. There was a significant correlation between the level of knowledge about cataract $(p=0.008)$ and level of education $(p=0,006)$ with preoperative visual acuity in patients with senile cataract. There was no correlation between socioeconomic status with preoperative visual acuity in patients with senile cataract $(\mathrm{p}=0.124)$.

Conclusion : The results showed that the factors affecting patients in seeking treatment of cataract was the level of knowledge about cataract and level of education. Patients with a good level of knowledge and good education were expected to recognize the symptoms of cataracts immediately and could search for cataract treatment to prevent blindness.
\end{abstract}

Keywords : Senile cataract, level knowledge, education, socioeconomic status, visual acuity

\footnotetext{
1) Student of Faculty of Medicine, Widya Mandala Catholic University Surabaya, Kalisari Selatan 1 Surabaya Email : ysumomba@gmail.com

2) Ophthalmology Department, Faculty of Medicine, Widya Mandala Catholic University Surabaya, Kalisari Selatan 1 Surabaya

3) Public Health Department, Faculty of Medicine, Widya Mandala Catholic University Surabaya, Kalisari Selatan 1 Surabaya
} 


\section{INTRODUCTION}

The eye is a vital organ for humans to obtain information in a visual form that is used to carry out daily activities. The health of this organ is an important factor in improving the quality of human resources. The decline in the sense of sight begins to occur from mild to severe ${ }^{(1)}$.

Cataracts are turbidity conditions in the fibers or lens material in the lens capsule. ${ }^{(2)}$ Cataracts come from the Greek word "kataarrhakies" which means waterfall. In Indonesian, cataracts are called bular, which is vision like a waterfall covered by a cloudy lens. ${ }^{(3)}$ In Indonesia, cataracts are still one of the leading causes of blindness. Estimated increase in cataract incidence is around $0.1 \%$ per year. ${ }^{(4,5)}$

The main management of cataracts is surgery. Surgical actions are carried out if there are surgical indications such as: cataracts have disrupted daily work even though the cataract is not mature, mature cataracts because if it becomes hypermaturated it will cause complications such as uveitis and glaucoma, and cataracts cause complications such as intestinal cataracts glaucoma and infection. ${ }^{(2)}$ Surgery or cataract surgery is divided into extracapsular cataract surgery, intracapsular cataract surgery, and phacoemulsification.

Several factors that play a role in the patient's attitude towards cataract surgery are knowledge, education, and socio-economic status. Based on Riskesdas data in 2013, the three main reasons for patients avoid cataract surgery were because they did not know if they had cataracts $(51.9 \%)$, economic factors $(11.9 \%)$, and were afraid of surgery $(4.5 \%) .^{(4,7)}$ In addition, according to the Riskesdas in East Java 2013, the reason for not having cataract surgery was because they did not know they had cataracts with a prevalence of 51.3\% and were unable to finance operations with a prevalence of $12.1 \% .^{(6,7,8)}$ Therefore, this study was conducted to determine the relationship between the level of patient knowledge about cataracts, education, and socio-economic status of patients with preoperative visual acuity at $\mathrm{PHC}$ Surabaya Hospital.

\section{METHODS}

The study was observational by using a type of analytic research with a cross-sectional approach, namely that each subject was only made one measurement at the time of examination.

The sample used in this study was preoperative senile cataract patients aged $\geq 50$ years old in August to September 
2016. The study was conducted on 24 August to 27 September 2016. Data was taken from medical records to see the visibility of respondents and provide questionnaires to determine the level of knowledge about cataracts, education, and socio-economic status. The inclusion criteria of this study were preoperative senile cataract patients in PHC Surabaya Hospital aged $\geq 50$ years old in August September 2016. The exclusion criteria for this study were patients who were not cooperative and patients had dementia. The number of research samples was 50 respondents.

This research uses data about the level of knowledge about cataracts carried out by questionnaires, educational data and socio-economic status carried out by interviews. Preoperative visual acuity data was taken by looking at the patient's medical records. Sampling was done through accidental sampling so that 50 respondents were sequentially fulfilling the selection criteria. The collected data was analyzed using SPSS and tested using Cronbach's Alpha.

\section{RESULT}

The characteristics of respondents in the study were based on age, gender, and level of vision. Complete data can be seen in the following table.
Table 1 Distribution of Age Preoperative Cataract Based Patients in PHC Surabaya Hospital Period 24 August - 27 September 2016

\begin{tabular}{lccc}
\hline No. & $\begin{array}{c}\text { Age } \\
\text { Group } \\
\text { (years) }\end{array}$ & $\begin{array}{c}\text { Frequency } \\
\text { (n) }\end{array}$ & $\begin{array}{c}\text { Percentage } \\
(\%)\end{array}$ \\
\hline 1 & $50-54$ & 8 & 16 \\
2 & $55-59$ & 6 & 12 \\
3 & $60-64$ & 14 & 28 \\
4 & $65-69$ & 9 & 18 \\
5 & $70-74$ & 10 & 20 \\
6 & $75-79$ & 3 & 6 \\
\hline \multicolumn{4}{c}{ Total } \\
\hline
\end{tabular}

Shown on table 1, the highest age was $60-64$ years old in $28 \%$ (14 patients) and the lowest age group was 75-79 years 6\% (3 patients). 60-64 group has a highest number possibly because starting at the age 60 , cataracts will affect vision more due to increased turbidity. In addition, 60 years old is the age of retirement so that patients have time to go to the hospital.

Table 2 Distribution of Preoperative Patients with Senile Cataracts Based on Gender in PHC Surabaya Hospital Period 24 August 27 September 2016

\begin{tabular}{cccc}
\hline No. & Gender & $\begin{array}{c}\text { Frequency } \\
(\mathbf{n})\end{array}$ & $\begin{array}{c}\text { Percentage } \\
(\mathbf{\%})\end{array}$ \\
\hline 1 & Man & 26 & 52 \\
2 & Woman & 24 & 48 \\
\hline & Total & 50 & 100 \\
\hline
\end{tabular}

Shown on table 2, the percentage of cataract preoperative patients by sex, male was 52\% (26 patients) and female was $48 \%$ (24 patients). There were more men than women, possibly because more men work, especially work done outdoors 
so they are exposed to the sun which can cause a risk of cataracts.

Table 3 Distribution of Preoperative Senilis Patients Based on Sharp Vision Preoperative Patients in Surabaya PHC Hospital Period 24 August-27 September 2016

\begin{tabular}{lccc}
\hline No. & $\begin{array}{c}\text { Sharp } \\
\text { eyesight }\end{array}$ & $\begin{array}{c}\text { Frequency } \\
\text { (n) }\end{array}$ & $\begin{array}{c}\text { Percentage } \\
(\%)\end{array}$ \\
\hline 1 & $>6 / 60$ & 12 & 24 \\
2 & $6 / 60->3 / 60$ & 6 & 12 \\
3 & $3 / 60->1 / 60$ & 10 & 20 \\
4 & $1 / 60-\mathrm{LP}+$ & 22 & 44 \\
\hline & Total & 50 & 100 \\
\hline
\end{tabular}

Shown on table 3 , the percentage of preoperative cataract patients based on the highest visual acuity was in 1/60 vision group - LP + which was 44\% (22 patients) and the lowest was in $6 / 60->3 / 60$ vision sharp group, $12 \%$ (6 patients).

Table 4 Cross Tabulation Distribution Level of Knowledge Regarding Cataracts with Sharp Vision Preoperative in Senile Cataract Patients in Surabaya PHC Hospital Period 24 August - 27 September 2016

\begin{tabular}{|c|c|c|c|c|c|c|c|}
\hline \multirow{3}{*}{\multicolumn{2}{|c|}{ Variable }} & \multicolumn{6}{|c|}{ Sharp Vision Preoperative Category } \\
\hline & & \multicolumn{2}{|c|}{$\begin{array}{l}\text { Blind and Nearly } \\
\text { Blind }\end{array}$} & \multicolumn{2}{|c|}{ Low Vision } & \multicolumn{2}{|c|}{$\begin{array}{l}\text { Normal and Nearly } \\
\text { Normal Vision }\end{array}$} \\
\hline & & n & $\%$ & $\mathbf{n}$ & $\%$ & $\mathbf{N}$ & $\%$ \\
\hline \multirow{4}{*}{$\begin{array}{c}\text { Categories of } \\
\text { Knowledge } \\
\text { Regarding } \\
\text { Cataracts } \\
\end{array}$} & Low Knowledge & 11 & 55 & 4 & 19 & 1 & 11,1 \\
\hline & $\begin{array}{c}\text { Enough } \\
\text { Knowledge }\end{array}$ & 8 & 40 & 16 & 76,2 & 7 & 77,8 \\
\hline & Good Knowledge & 1 & 5 & 1 & 4,8 & 1 & 11,1 \\
\hline & $\begin{array}{c}\text { Total } \\
\end{array}$ & 20 & 100 & 21 & 100 & 9 & 100 \\
\hline
\end{tabular}

Shown on table 4, most of subject in blind and almost blind categories have the low knowledge category, 11 patients $(55 \%)$ and the lowest in the good knowledge category is 1 patient (5\%). Most patient with low vision categories that have enough knowledge were 16 patients $(76.2 \%)$ and the lowest in the good knowledge category, 1 patient (4.8\%). Most categories of normal and almost normal vision have enough knowledge 7 patients (77.8\%) and the lowest in the low knowledge category and good knowledge, 1 patient (11.1\%).
Based on the test results of the relationship analysis between the level of knowledge regarding preoperative cataracts in senile cataract patients, $\mathrm{p}=$ 0.008 with a correlation coefficient $\mathrm{r}=$ 0.373 , it can conclude that there is a significant correlation between the level of knowledge about cataracts and preoperative visiual acuity in senile cataract patients, but the correlation strength is classified as weak $(r=0.20$ 0.399). The positive correlation coefficient $r$ means that the higher the level of knowledge about cataracts, the 
better the preoperative visual sharpness in senile cataract patients.

Table 5 Cross Tabulation of Education Level Distribution with Sharp Vision Preoperative in Senile Cataract Patients in Surabaya PHC Hospital Period 24 August - 27 September 2016

\begin{tabular}{|c|c|c|c|c|c|c|c|}
\hline \multirow{3}{*}{\multicolumn{2}{|c|}{ Variable }} & \multicolumn{6}{|c|}{ Sharp Vision Preoperative Category } \\
\hline & & \multicolumn{2}{|c|}{$\begin{array}{c}\text { Blind and Nearly } \\
\text { Blind }\end{array}$} & \multicolumn{2}{|c|}{ Low Vision } & \multicolumn{2}{|c|}{$\begin{array}{c}\text { Normal and Nearly } \\
\text { Normal Vision }\end{array}$} \\
\hline & & $\mathbf{n}$ & $\%$ & $\mathbf{N}$ & $\%$ & $\mathbf{N}$ & $\%$ \\
\hline \multirow{3}{*}{$\begin{array}{c}\text { Education } \\
\text { category }\end{array}$} & Low education & 16 & 80 & 7 & 33,3 & 3 & 33,3 \\
\hline & $\begin{array}{c}\text { Medium } \\
\text { Education }\end{array}$ & 2 & 10 & 12 & 57,2 & 4 & 44,5 \\
\hline & Higher education & 2 & 10 & 2 & 9,5 & 2 & 22,2 \\
\hline & tal & 20 & 100 & 21 & 100 & 9 & 100 \\
\hline
\end{tabular}

Shown on table 5 , most blind and almost blind categories have low education 16 patients $(80 \%)$ and the lowest number in the medium and tertiary education category 2 patients (10\%). Most low vision categories have medium education category 12 patients $(57.2 \%)$ and the lowest number in the higher education category, 2 patients $(9.5 \%)$. Most in categories of normal and almost normal vision have medium education category, 4 patients $(44.5 \%)$ and the lowest in the low education category, 2 patients $(22.2 \%)$.
Based on the test results of the relationship analysis between the level of education with preoperative visual acuity in senile cataract patients, $p=0.006$ with a correlation coefficient $r=0.384$, it can be said that there is a significant relationship between the level of education with preoperative vision in senile cataract patients, but the correlation strength classified as weak $(\mathrm{r}=0.20$ 0,399). The positive correlation coefficient $r$ means that the higher the level of education, the better the preoperative visual sharpness in senile cataract patient.

Table 6 Cross Tabulation of Distribution of Socio-Economic Status Levels with Sharp Vision Preoperative in Senile Cataract Patients in PHC Surabaya Hospital Period 24 August - 27 September 2016

\begin{tabular}{|c|c|c|c|c|c|c|c|}
\hline \multirow{3}{*}{\multicolumn{2}{|c|}{ Variable }} & \multicolumn{6}{|c|}{ Sharp Vision Preoperative Category } \\
\hline & & \multicolumn{2}{|c|}{ Blind and Nearly Blind } & \multicolumn{2}{|c|}{ Low Vision } & \multicolumn{2}{|c|}{$\begin{array}{c}\text { Normal and Nearly } \\
\text { Normal Vision }\end{array}$} \\
\hline & & $\mathbf{N}$ & $\%$ & $\mathbf{N}$ & $\%$ & $\mathbf{N}$ & $\%$ \\
\hline \multirow{3}{*}{$\begin{array}{c}\text { Category of } \\
\text { Socio-Economic } \\
\text { Status }\end{array}$} & Low education & 17 & 85 & 19 & 90,4 & 6 & 66.7 \\
\hline & $\begin{array}{c}\text { Medium } \\
\text { Education }\end{array}$ & 3 & 15 & 1 & 4,8 & 2 & 22,2 \\
\hline & Higher education & 0 & 0 & 1 & 4,8 & 1 & 11,1 \\
\hline \multicolumn{2}{|c|}{ Total } & 20 & 100 & 21 & 100 & 9 & 100 \\
\hline
\end{tabular}


Shown on table 6, the highest proportion in blind and almost blind categories was in low income category, 17 patients (85\%) and the lowest in the highincome category 0 patients $(0 \%)$. Most low vision categories were in the low income 19 patients (90.4\%) and the lowest in the medium and high-income category, 1 patient (4.8\%). Most categories of normal and almost normal vision was in the low income category, 6 patients $(66.7 \%)$ and the lowest in the high income category, 1 patient (11.1\%).

Based on the test results of the relationship analysis between socioeconomic status and preoperative visual acuity in senile cataract patients, $p=$ 0.124 with a correlation coefficient $\mathrm{r}=$ 0.389 it can be conclude that there is no significant relationship between socioeconomic status and preoperative visual acuity in senile cataract patsients.

\section{DISCUSSION}

Visual acuity of preoperative senile cataract patients is closely related to the level of knowledge of patients. Patients with good knowledge of cataracts can immediately seek cataract treatment so that the preoperative visual acuity that is obtained is in good condition. People who have good knowledge will immediately treat their cataracts to health centers or hospitals because they know about their condition and some complications of their condition. Someone who has good knowledge will immediately inflict cataracts so that before the surgery the patient's visual acuity is still not deteriorating. Conversely, if the knowledge is low, people tend to neglect their cataracts so that when performing surgery, the visual acuity has deteriorated..$^{(7,8,9,10)}$

In this study, the percentage of patients who have low knowledge is $32 \%$, enough knowledge 62\%, and good knowledge $6 \%$. Based on the Spearman correlation test, there was a significant relationship between the level of knowledge regarding cataracts with visual acuity preoperatively with a $p$ value of 0.008 . This is in line with study conducted by Bayu Setiawan. According to Bayu Setiawan (2013), the level of knowledge regarding cataract surgery has a close relationship with the attitude toward cataract surgery which affects the preoperative visual acuity of patients with a $\mathrm{p}$ value $=0.031$.

This result is also in line with the study conducted by Sofia Arditya and Fifin L. Rahmi (2007) in Dr. RSUP Kariadi Semarang with a $p$ value $(p)=$ 0.02. In this study, the percentage of patients who had less knowledge was 34\%, 
moderate knowledge was 38\%, good knowledge was $28 \%$,

Visual acuity of the preoperative senile cataract patient is closely related to the education level. Patients with a high level of education should be able to immediately seek cataract treatment so that preoperative visual acuity obtained was in good condition. ${ }^{(11,12,13,14,15,7)}$ Patients with low education levels have low awareness about cataracts so that the patient's visual acuity before surgery has deteriorated. ${ }^{(7,16,17)}$

In this study, the percentage of patients who have low education is $52 \%$, moderate education is $36 \%$, and higher education is $12 \%$. Based on the spearman correlation test, it was found that there was a significant relationship between the level of education with preoperative visual acuity with a $\mathrm{p}$ value $=0.006$. This is in line with the study conducted by $\mathrm{Ni}$ Nyoman Santi Tri Ulandari at the Public Health Center of West Nusa Tenggara with a $\mathrm{p}$ value $(\mathrm{p})=0.013{ }^{(9)}$

In this study we found the cause of the absence of a relationship between socioeconomic status and preoperative visual acuity in senile cataract patients at PHC Surabaya were:

1. Most of the patients have used BPJS which functions to organize health insurance programs for the community. With the existence of the BPJS, the patient can carry out cataract surgery quickly and at a lower cost. ${ }^{(18)}$

2. Most patients are retirees from Pelindo so that the cost of cataract surgery is borne by the company. This can reduce the patient's burden of paying for operating costs.

\section{CONCLUSION}

Based on the results of from this research to find the relationship between the level of knowledge regarding cataracts, education, and socioeconomic status with preoperative visual acuity in senile cataract patients at PHC Surabaya Hospital for 50 study samples that had met the inclusion criteria on August 24 to September 27 2016, we conclude that:

1. There is a significant relationship between the level of knowledge regarding cataracts and preoperative visual acuity in senile cataract patients.

2. There is a significant relationship between the level of education with preoperative visual acuity in senile cataract patients.

3. There is no significant relationship between socioeconomic status and preoperative visual acuity in senile cataract patients. 


\section{REFERENCES}

1. Vision 2020 The Right To Sight: Global Initiative for The Elimination of Avoidable Blindnes [internet]. Switzerland; World Health Organization; 2007 [cited 15 Feb 2016]. Diunduh dari: http://www.who.int/blindness/Vision2 020 report.pdf

2. Ilyas S. Penuntun Ilmu Penyakit Mata. Edisi Ketiga. Jakarta: Balai Penerbit Fakultas Kedokteran Universitas Indonesia. 2008.

3. Tamsuri A. Klien Gangguan Mata dan Penglihatan: Keperawatan Medikal-Bedah. Jakarta: Penerbit Buku Kedokteran EGC. 2010.

4. Herman S, Sudomo M, Suprapto A, editors. Pokok-pokok Hasil Riset Kesehatan Dasar Riskesdas 2013 Provinsi Jawa Timur. Jakarta: Lembaga Penerbitan Badan Penelitian dan Pengembangan Kesehatan. 2013.

5. Rencana Strategi Nasional Penanggulangan Gangguan Penglihatan dan Kebutaan Untuk Mencapai Vision 2020. Jakarta; Kementerian Kesehatan Republik Indonesia; 2005 [cited $01 \mathrm{Feb}$ 2016]. Diunduh dari: http://perpustakaan.depkes.go.id:8180/ bitstream/123456789/1030/3/KMK14 73-1005-G56.pdf

6. Situasi Gangguan Penglihatan dan Kebutaan. Jakarta; Kementerian Kesehatan Republik Indonesia; 2014 [cited 01 Feb 2016]. Diunduh dari: http://www.depkes.go.id/download.ph p? file=download/pusdatin/infodatin/in fodatin-penglihatan.pdf

7. Lewallen S, Courtright. Recognising and Reducing Barriers to Cataract Surgery. British Columbia Centre for Epidemiologic \& International Ophthalmology St Paul's Hospital, Vancouver, BC, Canada [internet]. 2000 [ cited 14 Mar 2016]. Diunduh dari:

http://www.ncbi.nlm.nih.gov/pmc/arti
cles/PMC1705969/pdf/jceh_13_34_02 $0 . p d f$

8. Pokok-pokok Riskesdas. Jakarta: Departemen Kesehatan Republik Indonesia; 2014 [cited 26 Apr 2016]. Diunduh dari: http://www.depkes.go.id/resources/do wnload/general/pokok2\%20hasil\%20r iskesdas\%202013.pdf

9. Ulandari NYST. Pengaruh Pekerjaan dan Pendidikan Terhadap Terjadinya Katarak pada Pasien yang Berobat di Balai Kesehatan Mata Masyarakat Nusa Tenggara Barat [Internet]. Bali; Universitas Udayana; 2014 [cited 15 Mar 2016]. Diunduh dari: http://www.pps.unud.ac.id/thesis/pdf thesis/unud-1070-697482586-tesis.pdf

10. Ilyas HS. Katarak: Lensa Mata Keruh. Edisi kedua. Jakarta: Balai Penerbit Fakultas Kedokteran Universitas Indonesia. 2006.

11. Riordan-Eva P, John PW. Oftalmologi Umum. In editor : Susanto, Diana. Jakarta : EGC; 2010.

12. Khaw PT, Shah P, Elkingston AR. $A B C$ of Eyes Fourth Edition. London : BMJ Books; 2004.

13. Agus. Daftar Gaji UMR Jatim Tahun 2016, Daftar Lengkap UMK 38 Kabupaten Dan Kota Di Jawa Timur 2016. Diunduh dari: http://www.gajiumr.com/gaji-umrjawa-timur/

14. Sujarweni VW. SPSS Untuk Penelitian. Yogyakarta: Penerbit Pustaka Baru Press.

15. Setiawan B. Hubungan Antara Pengetahuan Tentang Operasi Katarak dan Tingkat Ekonomi Penderita dengan Sikap Tentang Operasi Katarak Pada Penderita Katarak Lanjut Usia di Wilayah Kerja Puskesmas Sukoharjo. Surakarta; Universitas Muhammadiyah Surakarta; 2013 [cited 11 Mei 2016]. Diunduh dari: http://eprints.ums.ac.id/26027/18/NAS KAH_PUBLIKASI.pdf

16. Arditya KS, Rahmi FL. Hubungan Pengetahuan dengan Sikap Terhadap 
Operasi Katarak pada Pasien Katarak Senilis di RSUP Dr. Kariadi Semarang. Semarang; Fakultas Kedokteran Universitas Diponegoro; 2007 [cited 14 Nov 2016]. Diunduh dari:

http://www.journal.unair.ac.id/filerPD F/makalah\%204_Juli\%202007.pdf

17. Amalia I. Hubungan antara Pendidikan, Pendapatan, dan Perilaku Hidup Bersih dan Sehat pada Pedagang Hidangan Istimewa Kampung di Pasar Kliwon dan Jebres Kota Surakarta. Surakarta; Universitas Muhammadiyah Surakarta; 2009 [cited 20 Apr 2016]. Diunduh dari: http://eprints.ums.ac.id/26027/2/BAB I.pdf

18. Undang-undang Republik Indonesia Nomor 24 Tahun 2011 Tentang Badan Penyelenggara Jaminan Sosial Dengan Rahmat Tuhan Yang Maha Esa Presiden Republik Indonesia. Jakarta; Presiden Republik Indonesia; 2011 [cited 14 Nov 2016]. Diunduh dari: http://www.jamsosindonesia.com/ceta $\mathrm{k} /$ printout $/ 268$ 